\title{
Strongylids (Nematoda: Strongylidae) in two zebra species from the "Askania-Nova" Biosphere Reserve, Ukraine: biodiversity and parasite community structure
}

\author{
T. A. KUZMINA ${ }^{1}$, V. A. KHARCHENKO ${ }^{1}$, N. S. ZVEGINTSOVA ${ }^{2}$, L. ZHANG ${ }^{3}$, \\ J. LIU $^{3}$
}

\author{
${ }^{1}$ Institute of Zoology, NAS of Ukraine, vul. B. Khmelnyts'kogo, 15, Kyiv, 01601, Ukraine, \\ E-mail: taniak@izan.kiev.ua,vit@izan.kiev.ua; ${ }^{2}$ Biosphere Reserve “Askania Nova” UAAS, vul. Frunze, 13, Askania- \\ Nova, Kherson Region, 75230, Ukraine, E-mail: askazveg@rambler.ru; ${ }^{3}$ College of Life Sciences Hebei Normal \\ University, Shijiazhuang, Hebei 050016, P. R. China,E-mail: liujingze@mail.hebtu.edu.cn
}

\begin{abstract}
Summary
Species composition and structure of strongylid (Nematoda: Strongylidae) community were examined in 15 plains zebras (Equus burchelli) and 8 Grevy's zebra (Equus grevyi) kept in the "Askania-Nova" Biosphere Reserve (Ukraine). Strongylids were collected from zebras in vivo following deworming with the "Univerm" $(0.2 \%$ aversectin C, Russia). Twenty-two strongylid species ( 3 species of subfamily Strongylinae and 19 - of Cyathostominae) were found. In plains zebras, 21 strongylid species were found; from 3 to 14 species per host. In Grevy's zebras, 18 strongylid species were recorded; from 4 to 14 species per host. Cyathostominae dominated in the communities of both zebra species; they composed more then $99 \%$ of strongylid number. Comparison of strongylid biodiversity in plains zebras from the "Askania-Nova" reserve with data collected from four African countries showed low similarity of strongylid faunas in zebras from Ukraine and Africa; the strongylid community was similar to those of domestic ponies from the same area.
\end{abstract}

Keywords: Strongylidae; zebra; Equus grevyi; Equus burchelli; Askania-Nova; Ukraine

\section{Introduction}

Strongylids (Nematoda: Strongylidae) parasitize wild and domestic equids worldwide (Dvojnos \& Kharchenko, 1994; Lichtenfels et al., 2008). Species composition and structure of strongylid communities as well as transmission of these parasites are known to be affected by various ecological factors, such as climate, weather, geographic range, host density, etc. (Duncan, 1974; Ogbourne, 1975a, b, 1976; Dvojnos \& Kharchenko, 1994; Stromberg, 1997; Matthee et al., 2004; Thieltges et al., 2008; Kuzmina et al., 2011).

For captive equids, the animal-keeping conditions have a particular influence on the community of their parasites; for instance, the availability of pasture grazing ensures successful transmission of strongylids (Ogbourne, 1975a, b; Herd et al., 1985; Wells et al., 1998; Kuzmina, 2012; Reinemeyer \& Nielsen, 2012). The frequency of animal deworming has been shown to break the species richness of the strongylid community as well as its structure (Bucknell et al., 1996; Kuzmina \& Kharchenko, 2008). In addition, maintenance of different equid species on the same area, as occurs in natural reserves and zoos, facilitates the exchange of parasites and, undoubtedly, affects the development of their communities (Krecek et al., 1987a, b; Epe et al., 2001; Knafo, 2008; Kuzmina et al., 2009). From this point of view, examination of the strongylid communities of such "exotic" equids like zebras that co-mingle with other equid species in the "Askania-Nova" Biosphere Reserve is of particular interest for understanding the impact of various intrinsic and environmental factors on the parasite community.

Zebras have been housed in the "Askania-Nova" Biosphere Reserve (Kherson region, Ukraine) since its foundation in 1893 (Falz-Fein 1997). The population of zebras there is rather small, up to 20 animals within species, the plains zebras (Equus burchelli Gray, 1824) and Grevy's zebra (Equus grevyiOustalet, 1882). Four other equid species wild Przewalski's horses (Equus ferus przewalskii Pojakov, 1881), donkeys (Equus asinus L., 1758), Turkmen kulans (Equus hemionus kulan Groves \& Mazak, 1967) and Shetland ponies (Equus caballus L., 1758), also are kept in large enclosures in the "Askania-Nova" Biosphere Reserve. All animals graze together in large enclosures, however groups of different species stay apart and have limited opportunity of parasite exchange.

Surveillances of equid infections by intestinal parasites are conducted in the "Askania-Nova" Reserve mainly by coprological methods (Zvegintsova, 2003). Postmortem exa- 
minations of helminthes from 11 zebras of both species collected over fourteen years revealed 23 strongylid species (Zvegintsova \& Treus, 1999). However, analysis of prevalence, intensity or community structure in particular zebra species has not been performed. We had an opportunity to perform in vivo examination of the parasite communities of separate equid species in the "Askania-Nova" Biosphere Reserve following deworming of the hosts with a macrocyclic lactone drug.

The current study was performed to investigate the species composition and community structure of intestinal strongylids of plains and Grevy's zebras kept in the "AskaniaNova" Biosphere Reserve. We also analyzed the differences in biodiversity of strongylid communities of zebras kept in the Reserve in Ukraine with data of other authors (Le Roux, 1932; Round, 1968; Scialdo et al., 1982; Scialdo-Krecek, 1983; Krecek et al., 1987a, b; Matthee et al., 2004) who investigated the zebra strongylids in reserves and national parks in four African countries.

\section{Materials and methods}

Our studies were carried out in the Biosphere Reserve "Askania-Nova" in the South Ukraine (Kherson region, Ukraine, $46^{\circ} 29^{\prime}$ North and $33^{\circ} 58^{\prime}$ East) in $2004-2012$.

Twenty-three zebras of two species - 15 plains (Burchell's) zebras (E. burchelli) and 8 Grevy's zebras (E. grevyi) of different ages were included in the study. All zebras were kept and grazed in large enclosures (up to 80 ha) from April to November, and were moved to winter barns from December till end of March. Most of the zebras were born at the "Askania-Nova" Reserve; some of them (mainly Grevy's) were obtained from Czech and German zoos.

All zebras in the "Askania-Nova" Reserve have been regularly dewormed with several anthelmintics (with benzimidazoles up to 1999, and with macrocyclic lactones after 2000) twice a year (in April and in November). All animals involved in our study have not been treated with any anthelmintics at least for 4 months prior to the study. Fecal egg counts were carried out on the day before treatment (day 0) and 14 days after treatment (day 14) using the McMaster technique (Herd, 1992) with a sensitivity of 25 eggs per gram (EPG).

Strongylids were collected from zebras in vivo following their deworming with the macrocyclic lactone drug "Univerm" ( $0.2 \%$ aversectin C, PharmBioMed, Russia) at a dose rate of $0.1 \mathrm{mg}$ aversectin $/ \mathrm{kg}$ of body weight (Kuzmina et al., 2005). Fecal samples containing expelled parasites (200 g in each sample) were collected at 24, 36, 48 and $60 \mathrm{~h}$ after treatment. Samples were washed with tap water and examined for adult and larval strongylids under a stereomicroscope. All nematodes were collected manually, fixed in $70 \%$ ethanol and identified under light microscope by morphological criteria (Dvojnos \& Kharchenko, 1994; Lichtenfels et al., 2008). Nematodes were clarified in phenol-glycerin solution $(80 \%$ phenol, $20 \%$ glycerin) before identification. Totally, 10159 specimens of strongylids were collected and identified.
The Paleontological Statistics Software (PAST) (Hammer et al., 2001) was used for statistical analysis of the data. Three age groups - young (less then 4 years old), adult (from 4 to 12 years old) and old zebras (more then 12 years) were separated for analysis. The shape of the prevalence frequency distribution was determined for all strongylid species according to Bucknell et al. (Bucknell et al., 1996). The proportion of each species in the strongylid community of each host was calculated as the number of specimens of the particular species in relation to the total number of strongylids found. Comparison of biodiversity of strongylid communities in two zebra species was performed using previously published data collected from zebras and ponies at the "Askania-Nova" Biosphere Reserve (Zvegintsova \& Treus, 1999; Kuzmina et al., 2007).

\section{Results}

All zebras examined were infected with intestinal strongylids; the level of infection varied from 25 to 700 EPG (average $257.6 \pm 184.5$ ). Mean EPG value was $293.3 \pm 204.9$ EPG in plains zebras, and 190.6 \pm 122.4 in Grevy's zebras (Table 1). Statistically significant differences in EPG values in the two zebra species were not observed (MannWhitney test, $\mathrm{U}=47.5 ; \mathrm{z}=-0.78 ; \mathrm{p}=0.43)$. Also, statistically significant differences in EPG values were not observed between males and females (Mann-Whitney test, $\mathrm{U}=54.5 ; \mathrm{z}=-0.32 ; \mathrm{p}=0.74)$ as well as between three age groups of zebras (Mann-Whitney test, $\mathrm{p}>0.05$ ).

Table 1. Mean eggs/gram (EPG) value and number of strongylid species classified according to zebra species, sexes and age groups at the "Askania-Nova" Biosphere Reserve

\begin{tabular}{lccc}
\hline & $\begin{array}{c}\text { mean } \\
\text { EPG }\end{array}$ & $\begin{array}{c}\text { Number } \\
\text { of strongylid } \\
\text { species }\end{array}$ & $\begin{array}{c}\text { Number } \\
\text { of species } \\
\text { per host }\end{array}$ \\
\hline Plains zebras $(\mathrm{n}=15)$ & 293.3 & 21 & $8.5 \pm 3.2$ \\
Grevy's zebras $(\mathrm{n}=8)$ & 190.6 & 18 & $9.0 \pm 3.4$ \\
Males $(\mathrm{n}=15)$ & 246.7 & 22 & $8.5 \pm 3.1$ \\
Females $(\mathrm{n}=8)$ & 278.1 & 18 & $7.6 \pm 2.8$ \\
Youngzebras $(<4$ years $)$ & 291.7 & 19 & $8.5 \pm 2.5$ \\
Adultzebras $(4-12$ years $)$ & 192.5 & 19 & $8.6 \pm 3.5$ \\
Oldzebras $(>12$ years $)$ & 350.0 & 15 & $8.3 \pm 4.1$ \\
\hline
\end{tabular}

Strongyle eggs were not found in animals examined on 14 th day after treatment. Thus we concluded that all luminal stages of strongylids were expelled from the zebras' intestines.

Totally, twenty-two strongylid species: 3 species of large strongyles (subfamily Strongylinae) and 19 species of cyathostomes (subfamily Cyathostominae) were recovered in these zebras (Table 2).

In the plains zebras, 21 strongylid species were found; from 3 to 14 species (average $8.5 \pm 3.2$ ) per host. In the Grevy's zebras, 18 strongylid species were observed; from 4 to 14 species (average $9.0 \pm 3.4$ ) per host. 
Table 2. Strongylid species documented in two zebra species at the "Askania-Nova" Biosphere Reserve

\begin{tabular}{|c|c|c|c|c|}
\hline & Strongylid species & $\begin{array}{l}\text { Zebras - both } \\
\text { species } \\
\text { (Zvegintsova \& } \\
\text { Treus, 1999) }\end{array}$ & $\begin{array}{c}\text { Equus burchelli } \\
\text { (original data) }\end{array}$ & $\begin{array}{c}\text { Equus grevyi } \\
\text { (original data) }\end{array}$ \\
\hline \multicolumn{5}{|c|}{ Subfamily Strongylinae } \\
\hline 1. & Strongylus vulgaris (SVU) & + & + & - \\
\hline 2. & S. edentatus (SED) & + & - & - \\
\hline 3. & Triodontophorusserratus (TSE) & + & - & + \\
\hline 4. & T. brevicauda (TBR) & - & - & - \\
\hline 5. & T. tenuicollis (TTE) & - & - & - \\
\hline 6. & Craterostomumacuticaudatum(ACU) & - & + & + \\
\hline \multicolumn{5}{|c|}{ Subfamily Cyathostominae } \\
\hline 7. & Cyathostomum catinatum (CAT) & + & + & + \\
\hline 8. & C. pateratum (PAT) & - & + & + \\
\hline 9. & C. tetracanthum (TET) & - & + & - \\
\hline 10. & Coronocyclus coronatus (COR) & + & + & + \\
\hline 11. & C. labiatus (LAB) & + & + & + \\
\hline 12. & C. labratus (LBR) & - & + & + \\
\hline 13. & C. sagittatus (SAG) & + & - & - \\
\hline 14. & Cylicocyclus nassatus (NAS) & + & + & + \\
\hline 15. & C. ashworthi (ASH) & + & + & + \\
\hline 16. & C. elongatus(ELO) & + & + & - \\
\hline 17. & C. leptostomus (LEP) & + & + & + \\
\hline 18. & C. insigne (INS) & + & - & - \\
\hline 19. & Cylicostephanus calicatus (CAL) & + & + & + \\
\hline 20. & C. longibursatus (LON) & + & + & + \\
\hline 21. & C. minutus (MIN) & + & + & + \\
\hline 22. & C. hybridus (HYB) & - & + & + \\
\hline 23. & C. goldi $(\mathrm{GOL})$ & + & + & + \\
\hline 24. & C. bidentatus (BID) & + & + & - \\
\hline 25. & Cylicodontophorus bicoronatus (BIC) & + & + & + \\
\hline 26. & Parapoteriostomum mettami (MET) & - & + & + \\
\hline 27. & Poteriostomum imparidentatum (IMP) & + & + & + \\
\hline 28. & P. ratzii (RAT) & + & - & - \\
\hline 29. & Gyalocephalus capitatus(CAP) & + & - & - \\
\hline
\end{tabular}

Cyathostomes dominated the strongylid community of both zebra species; they composed $99.6 \%$ of strongylid community in the plains zebras and $99.8 \%$ of community in the Grevy's zebras. Four cyathostome species (C. nassatus, C. catinatum, C. longibursatus and C. goldi) dominated the strongylid community in the plains zebras; they were found in more than $80 \%$ of animals examined and to- gether composed $92 \%$ of total strongylid number (Fig. 1). Five cyathostome species (C. longibursatus, $C$. nassatus, C. goldi, C. catinatum and C. leptostomum) dominated the strongylid community of Grevy's zebras. They were found in more then $80 \%$ of the zebras and together composed $96 \%$ of total strongylid number (Fig. 2).

General structure of strongylid communities in two zebra 


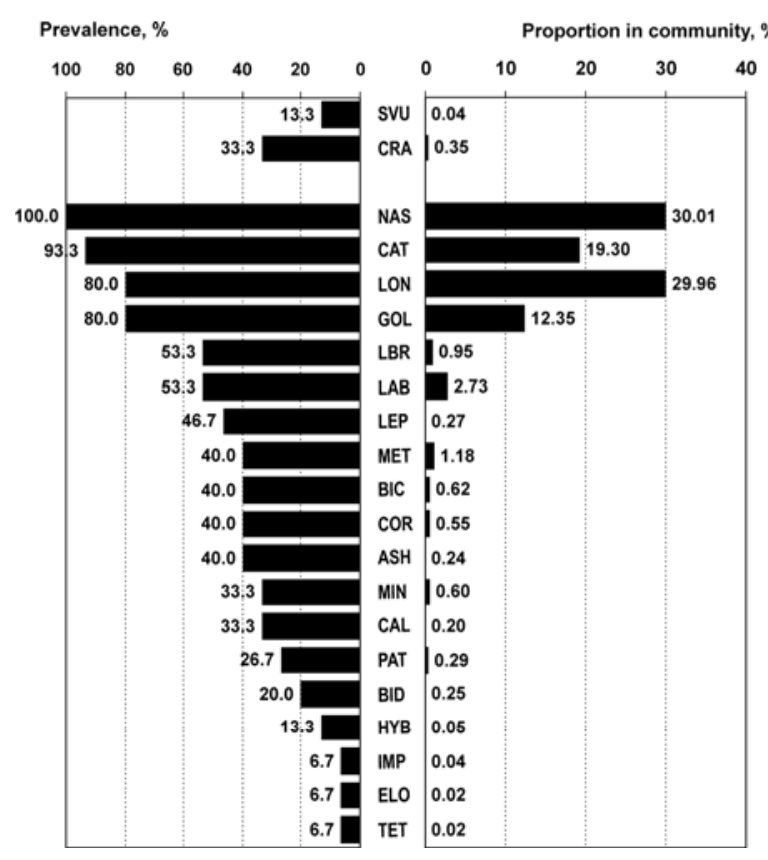

Fig. 1. Strongylid community of the plains zebras (E. burchelli) from the "Askania-Nova" Biosphere Reserve

species was different - in the plains zebras we observed multimodal structure of the strongylid community with dominant, subdominant, background and rare species (Fig. 3A). In the Grevy's zebras we observed bimodal structure of the community similar to "core - satellite mode" of community described by Hanski (1982) (Fig. 3B).

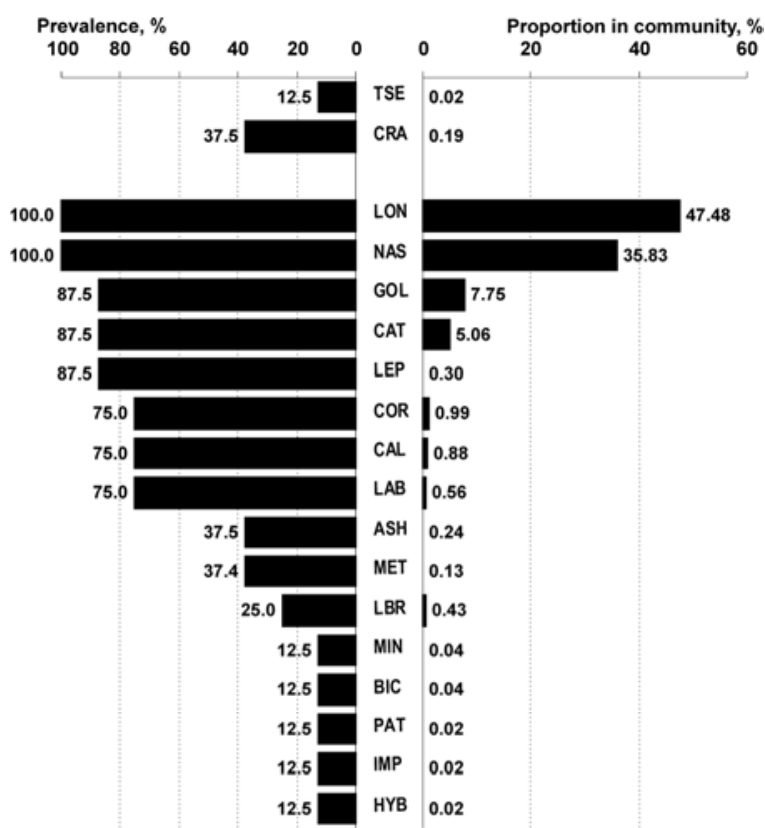

Fig. 2. Strongylid community of the Grevy's zebras (E. grevyi) from the "Askania-Nova" Biosphere Reserve

We also compared numbers of strongylid species found per one host in zebras of different sexes and age groups (Table 1). Statistically significant differences in number of species found males verses females were not observed (Mann-Whitney test, $\mathrm{U}=53 ; \mathrm{z}=-0.42 ; \mathrm{p}=0.67$ ). Also, statistically significant differences in number of strongylid

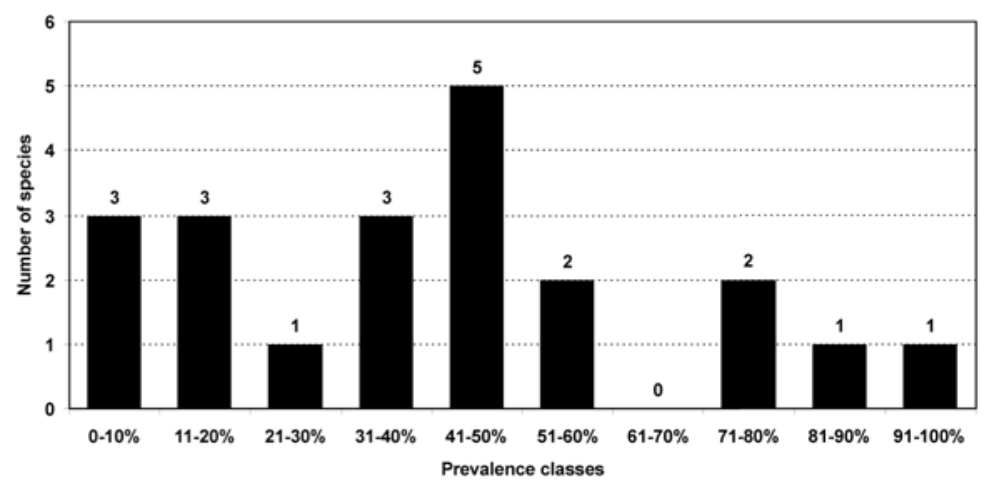

a

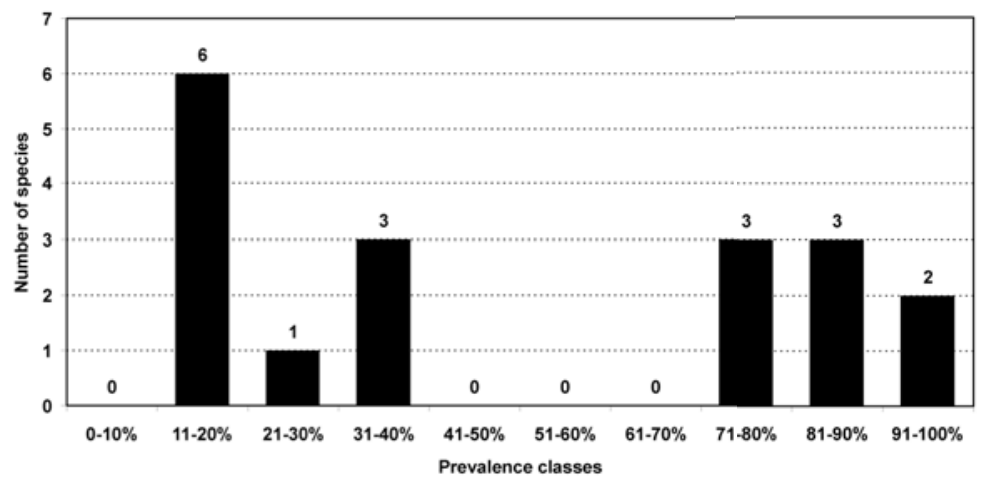

Fig. 3. Distribution of strongylid species from the plains zebras (A) and Grevy's zebras (B) on the prevalence classes 
Table 3. Strongylid species documented in plains zebras (Equus burchelli) at various countries

\begin{tabular}{|c|c|c|c|c|c|c|}
\hline & Strongylid species & \begin{tabular}{l}
\multicolumn{1}{c}{ Ukraine } \\
(Zvegintsova \& \\
Treus 1999; \\
original data) \\
\end{tabular} & $\begin{array}{c}\text { South Africa } \\
\text { (Scialdo-Krecek, } \\
\text { 1983; Krecek et al., } \\
\text { 1987) }\end{array}$ & $\begin{array}{c}\text { South Africa and } \\
\text { Namibia (Matthee } \\
\text { et al., 2004) }\end{array}$ & $\begin{array}{c}\text { Zambia } \\
\text { (Le Roux, 1932) }\end{array}$ & $\begin{array}{c}\text { Kenya } \\
\text { (Round, 1968) }\end{array}$ \\
\hline \multicolumn{7}{|c|}{ subfamilyStrongylinae } \\
\hline 1. & Strongylus vulgaris & + & - & - & - & - \\
\hline 2. & S. edentatus & + & - & - & - & - \\
\hline 3. & S. asini & - & - & + & - & - \\
\hline 4. & Oesophagodontus robustus & - & - & + & - & - \\
\hline 5. & Triodontophorus serratus & + & + & + & + & + \\
\hline 6. & T. brevicauda & - & - & - & - & - \\
\hline 7. & T. tenuicollis & - & - & - & - & - \\
\hline 8. & T. minor & - & + & + & - & - \\
\hline 9. & T. burchelli & - & + & + & - & - \\
\hline 10. & T. hartmannae & - & + & + & - & - \\
\hline 11. & Craterostomum acuticaudatum & + & + & + & - & + \\
\hline \multicolumn{7}{|c|}{ Subfamily Cyathostominae } \\
\hline 12. & Cyathostomum catinatum & + & + & + & + & - \\
\hline 13. & C. pateratum & + & - & + & - & - \\
\hline 14. & C. tetracanthum & + & - & - & - & - \\
\hline 15. & C. alveatum & - & + & + & + & - \\
\hline 16. & C. montgomeryi & - & + & + & - & - \\
\hline 17. & Coronocyclus coronatus & + & - & - & - & - \\
\hline 18. & C. labiatus & + & - & - & - & - \\
\hline 19. & C. labratus & + & - & - & - & - \\
\hline 20. & C. sagittatus & + & - & - & - & - \\
\hline 21. & Cylicocyclus nassatus & + & - & - & - & - \\
\hline 22. & C. ashworthi & + & + & + & - & - \\
\hline 23. & C. elongatus & + & - & - & - & + \\
\hline 24. & C. leptostomus & + & - & - & - & - \\
\hline 25. & C. insigne & + & + & + & + & - \\
\hline 26. & C. adersi & - & + & + & + & - \\
\hline 27. & C. auriculatus & - & + & + & - & + \\
\hline 28. & C. gyalocephaloides & - & + & + & - & + \\
\hline 29. & Cylicostephanus calicatus & + & + & + & - & - \\
\hline 30. & C. longibursatus & + & - & - & - & - \\
\hline 31. & C. minutus & + & + & + & - & - \\
\hline 32. & C. hybridus & + & - & - & - & - \\
\hline 33. & C. goldi & + & - & - & - & - \\
\hline 34. & C. bidentatus & + & + & + & - & - \\
\hline 35. & $\begin{array}{c}\text { Cylicodontophorus } \\
\text { bicoronatus }\end{array}$ & + & - & - & - & - \\
\hline 36. & C. reineckei & - & + & + & - & - \\
\hline 37. & C. schuermanni & - & + & + & - & - \\
\hline 38. & Cylindropharynx intermedia & - & + & + & + & - \\
\hline 39. & C. longicauda & - & - & - & + & + \\
\hline 40. & C. ornata & - & - & - & + & - \\
\hline 41. & C. rhodesiensis & - & - & - & + & - \\
\hline 42. & C. brevicauda & & & & & + \\
\hline 43. & Parapoteriostomum mettami & + & - & - & - & - \\
\hline 44. & $\begin{array}{l}\text { Poteriostomum } \\
\text { imparidentatum }\end{array}$ & + & - & - & - & - \\
\hline 45. & P. ratzii & + & + & + & + & - \\
\hline 46. & Gyalocephalus capitatus & + & - & - & - & - \\
\hline 47. & Skrjabinodentus longiconus & - & - & + & - & - \\
\hline
\end{tabular}

species per host were not found between three age groups (Mann-Whitney test; $p>0.05$ ).

Comparison of strongylid communities of plains zebras from the "Askania-Nova" Biosphere Reserve with data of other researchers who studied parasites of plains zebras in African countries and with our data collected from domes- 
Table 4. Similarity of strongylid biodiversity in plains zebras (Equus burchelli) from Ukraine and African countries

\begin{tabular}{|c|c|c|c|}
\hline Strongylid species & $\begin{array}{c}\text { Number of } \\
\text { strongylid species }\end{array}$ & $\begin{array}{c}\text { Number of } \\
\text { shared } \\
\text { species }\end{array}$ & $\begin{array}{l}\text { Chekanovsky- } \\
\text { Sorensen Index }\end{array}$ \\
\hline $\begin{array}{l}\text { Ukraine (Zvegintsova \& Treus, 1999; } \\
\text { and original data) }\end{array}$ & 28 & - & - \\
\hline $\begin{array}{l}\text { South Africa (Scialdo-Krecek, 1983; } \\
\text { Krecek et al., 1987) }\end{array}$ & 21 & 10 & 0.41 \\
\hline $\begin{array}{l}\text { South Africa and Namibia } \\
\text { (Matthee et al., 2004) }\end{array}$ & 24 & 10 & 0.39 \\
\hline Zambia (Le Roux, 1932) & 11 & 5 & 0.26 \\
\hline Kenya (Round, 1968) & 7 & 4 & 0.23 \\
\hline $\begin{array}{l}\text { Ponies from the "Askania-Nova" } \\
\text { (Kuzmina et al., 2007) }\end{array}$ & 27 & 22 & 0.8 \\
\hline
\end{tabular}

tic ponies from the "Askania-Nova" Reserve showed low similarity of strongylid faunas of zebras from Ukraine and from four African countries (Table 3 and 4). The strongylid community of zebras from the "Askania-Nova" Reserve was similar to the community of ponies from this reserve (Table 4).

The Bray-Curtis cluster analysis of strongylid communities of plains zebras based on comparison of our data with data of other studies in African countries (Scialdo-Krecek, 1983; Krecek et al., 1987a, b; Matthee et al., 2004; Le Roux, 1932; Round, 1968) (Table 3) and with our data collected from domestic ponies from the "Askania-Nove" reserve (Kuzmina et al., 2007) also showed that plains zebras from the "Askania-Nova" Biosphere reserve lost their "original" fauna of strongylids. Their strongylid community was more similar to that of domestic ponies kept on the same pastures (Fig. 4).

\section{Discussion}

This is the first comparative study of biodiversity and community structure of intestinal strongylids parasitizing two zebra species in the "Askania Nova" Biosphere Reserve. Previous published data on parasites of zebras in the reserve (Zvegintsova \& Treus, 1999) only provided a list of strongylid species found without any analysis of their communities.

In the present study, the level of zebra infection with strongylids was rather low - average fecal egg count in plains zebras was 293.3 EPG and in Grevy's zebras was 190.6 EPG. This is much lower than the fecal egg counts data in zebras from national parks and natural reserves in several African countries (Krecek et al., 1987a, b; Wambwa et al., 2004; Muoria et al., 2005; Knafo, 2008; Turner \& Getz, 2010). In our opinion, this is primarily a

\section{Bray-Curtis Cluster Analysis (Single Link)}

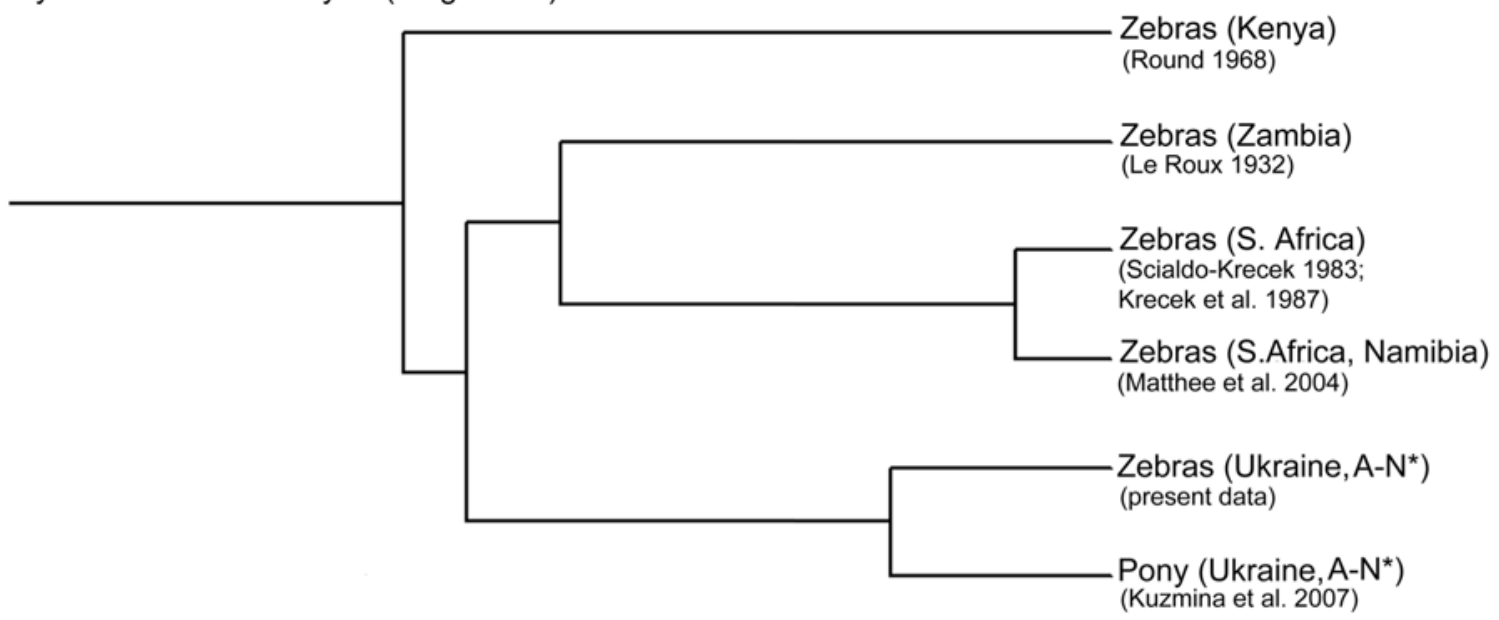

$0 \%$ Similarity

50

100

Fig. 4. Bray-Curtis cluster analysis of the strongylid community plains zebras (E. burchelli) from four African countries the“Askania-Nova" (A-N*) Biosphere Reserve 
consequence of routine deworming strategy in the "Askania Nova" Reserve twice a year, which significantly reduces the level parasitic infections, as it has been reported in domestic horses (Herd, 1990; Uhlinger, 1991; Lyons et al., 1999, 2012; Kuzmina \& Kharchenko, 2008; Reinemeyer \& Nilsen, 2012).

In our study there were no significant differences in levels of strongylid infections in zebras in regard to sex or age, as it has been previously reported in other equids (Wells et al., 1998; Francisco et al., 2009; Turner \& Getz, 2010; Fugazzola \& Stancampiano, 2012). The highest fecal egg count (350 EPG) was observed in animals older than 12 years, which may be associated with a reduction of antiparasitic immunity with their age (Foster, 1937; Love \& Duncan, 1992; Klei \& Chapman, 1999). However, these data were statistically insignificant.

Twenty-two strongylid species belonged to 10 genera were documented in this study. Thus, this present study expanded the list of strongylid species found in zebras kept in Ukraine up to 29 species. In African countries, 47 strongylid species were reported in zebras by several authors (Le Roux, 1932; Round, 1968; Scialdo-Krecek, 1983; Krecek et al., 1987a, b; Krecek et al., 1994; Matthee et al., 2004). Biodiversity of strongylid community in zebras in Ukraine is depleted - only $61.7 \%$ (29 species) of strongylid species registered in African countries were found here. Strongylid species typical for African zebras such as Triodontophorus burchelli, T. hartmannae, Cyathostomum montgomeryi, Cylicocyclus adersi, Cylicodontophorus reineckei, Parapoteriostomum schuermanni, or species from the genus Cylindropharynx (Scialdo-Krecek, 1983; Krecek et al., 1987a, b; Matthee et al., 2004) were not found in Ukraine. Apparently, the climatic conditions in the south of Ukraine with cold frosty winters may have had a destructive effect on the free-living stages of these "heatloving" species and prevent their survival on pasture and transmission.

Small strongyles (Cyathostominae) dominated the strongylid communities of both zebra species - they composed more then $99 \%$ of strongylid number. Only 3 species of large strongyles (Strongylinae) - S. vulgaris, T. serratus and $C$. acuticaudatum were found in this study, whereas 5 species of Strongylinae with prevalence more then $60 \%$ were recorded in zebras in the 1980 - 90s (Zvegintsova \& Treus, 1999). In our opinion, decline of large strongyle infections of zebras in the "Askania-Nova" Reserve is connected with wide use of macrocyclic lactone anthelminthics (ivermectin, aversectin, etc.) to control parasitic nematodes during last decades. The same trend of elimination of large strongyles from community of horse parasites is observed nowadays in many countries, where cyathostomes became the most common and pathogenic nematodes in domestic horses (Herd, 1990; Uhlinger, 1991; Love et al., 1999; Lyons et al., 1999; Kaplan, 2002; Kuzmina \& Kharchenko, 2008). Moreover, frequent dewormings of horses may lead to the destruction of strongylid community structure converting mutlimodal structure of the community (with dominant, subdominant, back- ground and rare species) to bimodal structure ("core-satellite" mode) (Bucknell et al., 1996; Kuzmina et al., 2007; Kuzmina \& Kharchenko, 2008). Only the most abundant cyathostome species with high genetic variability can survive regular treatments and develop resistance to anthelmintics to dominate in the strongylid community.

Comparison of our data on biodiversity of strongylid community in plains zebras from the "Askania Nova" Biosphere Reserve with similar data from African countries (Scialdo-Krecek, 1983; Krecek et al., 1987a, b; Le Roux, 1932; Round, 1968; Matthee et al., 2004) showed rather low similarity of strongylid faunas. Zebras from the "Askania-Nova" reserve lost their "original" strongylid fauna, and now species composition and structure of their strongylid community is more similar to that of domestic ponies kept in the reserve.

\section{Acknowledgments}

The authors would like to thank to Egor Yakovlev, MS (Institute of Zoology NAS of Ukraine) for his assistance in field work at the "Askania-Nova" Biosphere reserve, and Dr. Yuriy Kuzmin, PhD Institute of Zoology NAS of Ukraine) and Prof. Terry R. Spraker (Colorado State University, USA) for their help and valuable advices in preparation of the manuscript.

The studies were performed with partial financial support from the State Agency on Science, Innovation and Informatization of Ukraine and the Ministry of Science and Technology of the People's Republic of China for 2011 2012 (agreements No. M/186-2012 and No. CU08-14).

\section{References}

Bucknell, D., Hoste, H., Gasser, R. B., Beveridge, I. (1996): The structure of the community of strongyloid nematodes of domestic equids. J. Helminthol., 70: $185-$ 192. DOI: 10.1017/S0022149X0001539X

DUNCAN, J. L. (1974): Field studies on the epidemiology of mixed strongyle infection in the horse. Vet. Rec., 94 (15): 337 - 345. DOI:10.1136/vr.94.15.337

Dvojnos, G. M., KharchenKo, V. A. (1994): Strongylida of wild and domestic horses. Naukova Dumka, Kiev. 234 pp. (In Russian).

Epe, C., Kings, M., Stoye, M., Böer, M. (2001): The prevalence and transmission to exotic equids (Equus quagga antiquorum, Equus przewalskii, Equus africanus) of intestinal nematodes in contaminated pasture in two wild animal parks. J. Zoo Wildl. Med., 32(2): 209 - 216. DOI: 10.1638/1042-7260(2001)032[0209:TPATTE]2.0.CO;2

FAlz-FeIN, V. E. (1997): Askania-Nova. Kyiv, Agrarna Nauka (In Russian)

FOSTER, A. O. (1937): A relationship in equines between age of host and number of strongylid parasites. Am. J. Hyg., 25: 66 - 75 .

Francisco, I., ARIAS, M., CORTIŃAS, F. J., Francisco, R., Mochales, E., Dacal, V., Suárez, J. L., Uriarte, J., Morrondo, P., SÁnchez-Andrade, R., DíEz-BAŃos, P., 
PAZ-SILVA, A. (2009): Intrinsic factors influencing the infection by helminth parasites in horses under an oceanic climate area (NW Spain). J. Parasitol. Res., Article ID 616173, DOI: 10.1155/2009/616173

Fugazzola, M. C. And Stancampiano, L. (2012): Host social rank and parasites: Plains zebra (Equus quagga) and intestinal helminths in Uganda. Vet. Parasitol., $188(1-2)$ : 115 - 119. DOI: 10.1016/j.vetpar.2012.03.019

HAMMER, Ø., HARPER, D. A. T., RYAN, P. D. (2001): PAST: Paleontological Statistics Software Package for Education and Data Analysis. Paleontol. Electron., 4(1): 9pp. Retrieved from http://palaeo-electronica.org/2001_1/past/issue1_ 01.htm

HANSKI, I. (1982): Dynamics of regional distribution: The core and satellite hypothesis. Oikos, 38 (2): $210-221$. DOI: $10.2307 / 3544021$

HERD, R. P. (1990): Equine parasite control - problems associated with intensive anthelmintic therapy. Equine Vet. Educ., 2 (1): 41 - 47. DOI: 10.1111/j.2042-3292.1990.tb01 378.x

HerD, R. P. (1992): Performing equine fecal egg counts. Vet. Med., 87: 240 - 244

Herd, R. P., Willardson, K. L., Gabel, A. A. (1985): Epidemiological approach to control of horse strongyles. Equine Vet. J., 17: 202 - 207. DOI: 10.1111/j.20423306.1985.tb02470.x

KAPLAN, R. M. (2002): Anthelmintic resistance in nematodes of horses. Vet. Res., 33: 491 - 507. DOI: 10.1051/vetres:2002035

Klei, T. R. And Chapman, M. R. (1999): Immunity in equine cyathostome infections. Vet. Parasitol., 85 (2 - 3): 123 - 136. DOI: 10.1016/S0304-4017(99)00093-X

Knafo, S. E. (2008): Distribution of Gastrointestinal Parasites of Grevy's Zebras, Plains Zebras, Domestic Donkeys, and Domestic Cattle in the Samburu Landscape, Kenya. DVM Thesis, North Grafton, Kenya, 18p.

KreceK, R. C., Reinecke, R. K. And Malan, F. S. (1987a): Studies on the parasites of zebras. V. Nematodes of the Burchell's and Hartmann's mountain zebras from the Etosha National Park, South West Africa/Namibia. Onderstepoort J. Vet. Res., 54: $71-78$

KreceK, R. C., Malan, F. S., Reinecke, R. K., De Vos, V. (1987b): Nematode parasites from Burchell's zebras in South Africa. J. Wildl. Dis., 23: 404 - 411. DOI: 10.7589/0090-3558-23.3.404

Krecek, R. C., Reinecke, R. K., Kriek, N. J. P., HoraK, I. G., Malan, F. S. (1994): Helminth parasites of Cape mountain zebras from Cape province, South Africa. J. Wildl. Dis., 30: 277 - 280. DOI: 10.7589/0090-3558-30.2.277

KuZMinA, T. A. (2012): Contamination of the environment by strongylid (Nematoda: Strongylidae) infective larvae at horse farms of various types in Ukraine. Parasitol. Res., 110 (5): 1665 - 1674. DOI: 10.1007/s00436-011-2684-x Kuzmina, T. A., Kharchenko, V. A., Starovir, A. I., Dvojnos, G. M. (2005): Analysis of the strongylid nematodes (Nematoda: Strongylidae) community after deworming of brood horses in Ukraine. Vet. Parasitol., 131 (34): 283 - 290. DOI: 10.1016/j.vetpar.2005.05.010
Kuzmina, T. A., Kharchenko, V. A., Zvegintsova, N. S. (2007): Comparative study of the intestinal strongylid communities of equidae in the Askania-Nova biosphere reserve, Ukraine. Helminthologia, 44 (2): 62 - 69. DOI: 10.2478/s11687-007-0005-9

KuZMinA, T. A. AND KHARCHENKO, V. O. (2008): Anthelmintic resistance in cyathostomins of brood horses in Ukraine and influence of anthelmintic treatments on strongylid community structure. Vet. Parasitol., 154 (3 4): 277 - 288. DOI: 10.1016/j.vetpar.2008.03.024

Kuzmina, T. A., KharchenKo, V. A., Zvegintsova, N. S. (2009): Structure of strongylid communities in wild and domestic equids in Ukraine. Vestn. Zool., Suppl. 23: $107-$ 118 (In Russian)

KuZmina, T., Kornaś, S., BasiagA, M., KharchenKo, V., VYNIARSKA, A. (2011): Biodiversity of strongylids (Nematoda: Strongylidae) communities in domestic horses from Poland and Ukraine. Helminthologia, 48 (2): 77 - 84. DOI: $10.2478 / \mathrm{s} 11687-011-0013-7$

LE RouX, P. L. (1932): List of helminthes collected from mammals and birds in the Mazabuka area, Northern Rhodesia. Rep. Dept. Anim. Health Northern Rhod., Appendix B: $31-34$

Lia, R. P., Traversa, D., Laricchiuta, P., DantasTorres, F., Paradies, R., Alvinerie, M., KreceK, R. C., OTRANTO, D. (2010): Efficacy of an in-feed formulation containing ivermectin for the control of intestinal strongyles in captive zebras (Equus burchelli (Gray, 1824)). Vet. Parasitol., 169 (1- 2): 133 - 137. DOI: 10.1016/j.vetpar.2009.12.028

Lichtenfels, J. R., Kharchenko, V. A., Dvojnos, G. M. (2008): Illustrated identification keys to strongylid parasites (Strongylidae: Nematoda) of horses, zebras and asses (Equidae). Vet. Parasitol., $156(1-2): 4$ - 161. DOI: 10.1016/j.vetpar.2008.04.026

Love, S. AND DunCAN, J. L. (1992): The development of naturally acquired cyathostome infection in ponies. Vet. Parasitol., 44 (1 - 2): 127 - 142. DOI: 10.1016/03044017(92)90151-X

Love, S., Murphy, D. Mellor, D. (1999): Pathogenicity of cyathostome infection. Vet. Parasitol., 85 (2 - 3): 113 122. DOI: 10.1016/S0304-4017(99)00092-8

Lyons, E. T., Tolliver, S. C., Drudge, J. H. (1999): Historical perspective of cyathostomes: prevalence, treatment and control programs. Vet. Parasitol., 85 (2 - 3): 97 112, DOI: 10.1016/S0304-4017(99)00091-6

Lyons, E. T., Tolliver, S. C., KuzminA, T. A. (2012): Investigation of strongyle EPG values in horse mares relative to known age, number positive, and level of egg shedding in field studies on 26 farms in Central Kentucky (2010-2011). Parasitol. Res., 110 (6): 2237 - 2245. DOI: 10.1007/s00436-011-2755-z

Matthee, S., KreceK, R. C., McGeoch, M. A. (2004): A comparison of the intestinal helminth communities of Equidae in Southern Africa. J. Parasitol., 90 (6): 1263 1273. DOI: $10.1645 / \mathrm{GE}-3353$

Muoria, P. K., Muruthi, P., Rubenstein, D., Oguge, N. O., Munene, E. (2005): Cross-sectional survey of gastro- 
intestinal parasites of Grevy's zebras in Southern Samburu, Kenya. Afr. J. Ecol., 43 (4): 392 - 395. DOI: 10.1111/ j.1365-2028.2005.00588.x

OGBourne, C. P. (1975a): Studies on the epidemiology of Strongylus vulgaris infection of the horse. Int. J. Parasitol., 5 (4): 423 - 426. DOI: 10.1016/0020-7519(75)90008-9

OGBourne, C. P. (1975b): Epidemiological studies on horses infected with nematodes of the family Trichonematidae (Witenberg, 1925). Int. J. Parasitol., 5 (6): 667 - 672. DOI: 10.1016/0020-7519(75)90067-3

OGBourne, C. P. (1976): The prevalence, relative abundance and site distribution of nematodes of the subfamily Cyathostominae in horses killed in Britain. J. Helminthol., 50 (3): 203 - 214. DOI: 10.1017/S0022149X00027760 REINEMEYER, C. R. AND NiElSEN, M. K. (2012): Handbook of Equine Parasite Control. John Wiley \& Sons, 210 pp. Round, M. C. (1968): Checklist of the helminth parasites of African mammals of the orders Carnivora, Tubilidentata, Proboscidea, Hyracoidea, Artiodactyla and Perissodactyla. Technical Communication 38, Commonwealth Bureau of Helminthology, St. Albans, pp. i-vi, $1-252$

ScIAldo, R. C., Reinecke, R. K., DE Vos, V. (1982): Seasonal incidence of helminths in the Burchell's zebra. Onderstepoort J. Vet. Res., 49: 127 - 130

SCIALDO-KRECEK, R. C. (1983): Studies on the parasites of zebras. 1. Nematodes of the Burchell's zebra in the Kruger National Park. Onderstepoort J. Vet. Res., 50: 111 - 114

STROMBERG, B. E. (1997): Environmental factors influencing transmission. Veterinary Parasitology, 72 (3 - 4): 247
- 256. DOI: 10.1016/S0304-4017(97)00100-3

Thieltges, D. W., Jensen, K. T. And Poulin, R. (2008): The role of biotic factors in the transmission of free-living endohelminth stages. Parasitology, 135(4): 407 - 426. DOI: $10.1017 / \mathrm{S} 0031182007000248$

TURNER, W. C. AND GeTZ, W. M. (2010): Seasonal and demographic factors influencing gastrointestinal parasitism in ungulates of Ethosha national park. J. Wildl. Dis., 46 (4): 1108 - 1119. DOI: 10.7589/0090-3558-46.4.1108

UHLINGER, C. (1991): Equine small strongyles: Epidemiology, pathology and control. Compend. Contin. Educ. Vet., 13: $863-869$

Wambwa, E. N., Ogara, W. O., Mudakha, D. (2004): A comparative study of gastrointestinal parasites between ranched and free ranging Burchell's zebra (Equus burchelli antiquorum) in Isiolo district, Kenya. J. Vet. Sci., 5 (3): $215-220$

Wells, D., KreceK, R. C., Wells, M., Guthrie, A. J., LOURENS, J. C. (1998): Helminth levels of working donkeys kept under different management systems in the Moretele 1 district of the North-West Province, South Africa. Vet. Parasitol., 77 (2 - 3): 163 - 177. DOI: 10.1016/S0304-4017(98)00105-8

Zvegintsova, N. S. And Treus, M. Ju. (1999): The investigation of the parasitofauna of zebra in Askania-Nova. Vestn. Zool., Suppl. 11: 98 - 101 (In Russian)

ZvegintSOVA, N. S. (2003): History of parasitological surveys in the "Askania-Nova" reserve. Visti Biosphernogo zapovidnyka «Askania-Nova», 5: 169 - 181 (In Russian) 